\title{
Giant Cell Angioblastoma
}

National Cancer Institute

\section{Source}

National Cancer Institute. Giant Cell Angioblastoma. NCI Thesaurus. Code C97076.

A rare, slow-growing, locally aggressive soft tissue tumor characterized by the presence

of oval to spindle cells forming concentric aggregates around small vessels. Giant

multinucleated cells are also present. 